\title{
The effect of static and dynamic balance training on balance in children with congenital blindness
}

\author{
Doğuştan görmeyen çocuklarda statik ve \\ dinamik denge eğitiminin denge üzerine etkisi
}

\author{
[D Bilge Başakçı Çalık, ${ }^{1}$ (D) Ummuhan Bas Aslan,, (1) Sehmus Aslan, ${ }^{2}$ () Elif Gur Kabul' \\ 'School of Physical Therapy and Rehabilitation, Pamukkale University, Denizli, Turkey \\ ${ }^{2}$ Faculty of Sport Sciences, Pamukkale University, Denizli, Turkey
}

\begin{abstract}
Introduction: Visual information is very important in predicting the speed of body segments and objects and providing balance, as well as in the timing of psychomotor responses. The maintenance of posture and balance is negatively affected by partial or total loss of vision. The purpose of this study was to examine the effectiveness of static and dynamic balance training on balance in children with congenital blindness.

Methods: The study included 18 congenitally blind children, comprising 9 males and 9 females with a mean age of $10.94 \pm 1.89$ years. All participants were attending a special primary/secondary school for the blind. Balance functions were evaluated at baseline and at the end of the training program using the Balance Subtests of the Bruininks-Oseretsky Motor Proficiency Test Short Form (BOT2, SF), Timed Up and Go Test, the Functional Reach Test and the One Legged Stance Test. The training program of static and dynamic balance exercises was applied twice weekly for 8 weeks.

Results: A significant improvement was determined in all the balance tests after the training program $(p<0.05)$.

Discussion and Conclusion: The results of this study demonstrated that balance-specific static and dynamic exercises contribute to improvements in the balance of children with congenital blindness. Therefore, balance exercises should be to rehabilitation programs to improve the balance of children with congenital blindness.
\end{abstract}

Keywords: Children; congenital blindness; exercise; postural balance.

$\mathrm{B}^{\mathrm{a}}$ alance is defined as the ability to maintain the center of gravity of the body on the supporting surface and is considered within the concept of co-ordination. Co-ordination is the ability to perform appropriate, smooth, controlled move-
Özet

Amaç: Görsel bilgi, vücut segmentlerinin ve nesnelerin hızının tahmin edilmesinde ve psikomotor cevapların zamanlamasının yanı sıra dengenin sağlanmasında çok önemlidir. Kısmi veya total görme kaybı nedeniyle postür ve denge tutumu olumsuz etkilenir. Bu çalışmanın amacı konjenital görmeyen çocuklarda statik ve dinamik denge eğitiminin denge üzerindeki etkisini incelemektir.

Gereç ve Yöntem: Çalışmaya 18 konjenital görmeyen çocuk (10.94 \pm 1.89 yıl, 9 kız, 9 erkek) dahil edildi. Tüm katılımcılar görme engellilere özel bir ilkokul / ortaokula devam ediyorlardı. Denge fonksiyonları, eğitim programının başlangııında ve sonunda değerlendirildi. Denge fonksiyonlarını Bruininks-Oseretsky Motor Yeterlilik Testi Kısa Formu (BOT-2, SF)'nun denge alt testi, Süreli Kalk Yürü Testi, Fonksiyonel Uzanma Testi ve Tek Ayak Üzerinde Durma Testi ile değerlendirildi. Katılımcılara 8 hafta boyunca haftada iki kez statik ve dinamik denge egzersizleri içeren bir eğitim programı uygulandı.

Bulgular: Eğitim programından sonra tüm denge testlerinin sonuçlarında gelişme görüldü $(p<0,05)$

Sonuç: Çalışmamızın sonucunda konjenital görmeyen çocuklarda dengeye özgü statik ve dinamik egzersizlerin dengeyi geliştirmeye katkı sağladığı görülmüştür. Bu nedenle, konjenital görmeyen çocukların dengesini geliştirmek için rehabilitasyon programlarına denge egzersizlerinin eklenmesi ve yaygınlaştırılması gerektiğine inanıyoruz. Anahtar Sözcükler: Çocuk; doğuştan görmeyen; egzersiz; postüral denge.

ments. ${ }^{[1]}$ Motor co-ordination is required for the use of fine motor skills, the realization of professional activities involving walking, running, jumping and most daily life activities. Coordinated movements require proper alignment and timing

Corresponding (illetişim): Bilge Başakçı Çalık, Pamukkale Üniversitesi Fizik Tedavi ve Rehabilitasyon Yüksekokulu, Denizli, Turkey 
of synergistic and reciprocal muscle activities associated with good balance and posture function. Very complicated neuromuscular mechanisms are necessary for the maintenance of balance during activities and to provide erect posture. ${ }^{[2,3]}$

The visual, proprioceptive and vestibular systems must work together to provide balance. ${ }^{[4]}$ The visual and somotosensorial systems interact to control the stability and orientation of the body segments. Visual information is very important in predicting the velocity of body segments and objects and in providing balance as well as in the timing of psychomotor responses. ${ }^{[5,6]}$ Partial or total loss of vision has a negative effect on the maintenance of posture and balance. ${ }^{[7,8]}$ Therefore, loss of balance has been reported in many comparative studies of healthy subjects with visually impaired subjects. ${ }^{[7,9-17]}$

Balance has two subsections of static and dynamic balance. Static balance is defined as the ability to control postural release during an inactive standing posture. To maintain static balance, the center of gravity of the body must pass through the second sacral vertebra level and remain on the supporting surface. Dynamic balance is defined as the ability to predict postural changes that occur during motion and to give appropriate responses to these changes. ${ }^{[18]}$ The lack of, or an inadequate visual sense leads to problems in achieving and preserving balance for people with visual impairment. In visually impaired children and adolescents, the impairment of postural control and poor balance cause difficulties and a slowing down of walking speed. ${ }^{[19]}$ Many researchers have reported that visual impairment significantly increases the risk of falls by causing gait problems, impaired balance, and postural oscillations. Researchers have emphasized the importance of physical exercise programs for the development of the balance function in people with visual impairment. ${ }^{[20]}$

A previous study examining balance training in visually impaired children and adolescents concluded that dynamic balance training improves dynamic balance. ${ }^{[21]}$ To the best of our knowledge, there has been no previous study examining the effectiveness of static and dynamic balance training in visually impaired children and adolescents. The aim of this study was to examine the effectiveness of static and dynamic balance training on balance functions in visually impaired children.

\section{Materials and Method}

The study included 18 congenitally blind children, all of whom were attending a special primary/secondary school for the blind. The 18 congenitally blind children, comprising 9 males and 9 females with a mean age of $10.94 \pm 1.89$ years were applied with a balance training program and balance functions were evaluated. The dominant foot was the right side in 17 (94.47\%) children and left side in 1 (5.6\%). The children included in the study were those with congenital blindness with no other neurological or orthopedic problems that could affect balance, and who could understand the instructions during the implementation of the exercises and tests. The di- agnosis of congenital blindness of the participants was made in a health report from the state hospital at the time of school registration. All participants was in total blind (no light perception) and early time visual loss.

This study was approved by the Clinical Research Ethics Committee of Pamukkale University Faculty of Medicine (decision dated, 03/05/2016). All procedures were conducted according to the principles of the Declaration of Helsinki. The study was explained to the parents and school administrators. Written informed consent was obtained from the parents or legal guardian of each child.

The evaluations were made by the same physiotherapist before and after the training programme.

\section{Outcome measures}

1-Bruininks-Oseretsky Motor Proficiency Test Short Form (BOT-2, SF)

The BOT-2, SF to measure the motor skills of children in the $4.5-21$ years age range, was developed by Robert $\mathrm{H}$. Bruininks. ${ }^{[22]}$ This test battery is a tool used by educators, therapists, and researchers to assess children's motor competence, evaluate training programs, and to detect and evaluate various motor skills disorders and developmental disabilities. The Balance Sub-Tests of BOT-2 SF were used in this study. In the test, a maximum of two trials are allowed. If the child could not reach the highest score on the first attempt, he / she performed the second test.

BOT - 2 Balance Subtests

Walking Forward on a Line: The child stands with hands on hips and feet together, with the preferred foot on and parallel to the line and is instructed to move forward. The test was stopped when 6 steps were completed. Steps that did not float out were scored in the evaluation. The highest score in this test is 4.

Standing on One Leg on a Balance Beam:The child stands with hands on hips with the preferred foot on the balance beam and the non-preferred foot on the floor. The non-preferred leg is raised behind with the knee bent at $90^{\circ}$ and the shin parallel to the floor, and looks at the target. The child must hold this position for 10 seconds to reach the maximum score of 4 .

\section{2-Timed Up and Go Test}

The child is instructed to get up from a chair, walk 3 meters at normal speed and rhythm then turn around, walk back, and sit down. The time of this process was recorded in seconds. ${ }^{[23]}$

\section{3-Functional Reach Test}

Functional Reach Test is defined as the maximum distance one can reach forward beyond arm's length while maintaining a fixed base of support in the standing position. It is a method for testing dynamic standing balance. ${ }^{[18]}$

\section{4-One Legged Stance Test}

Barefoot, the child stands on one leg with the foot flat on the floo and the other foot resting against the inside of the knee 


\section{Table 1. The content of the exercise programs}

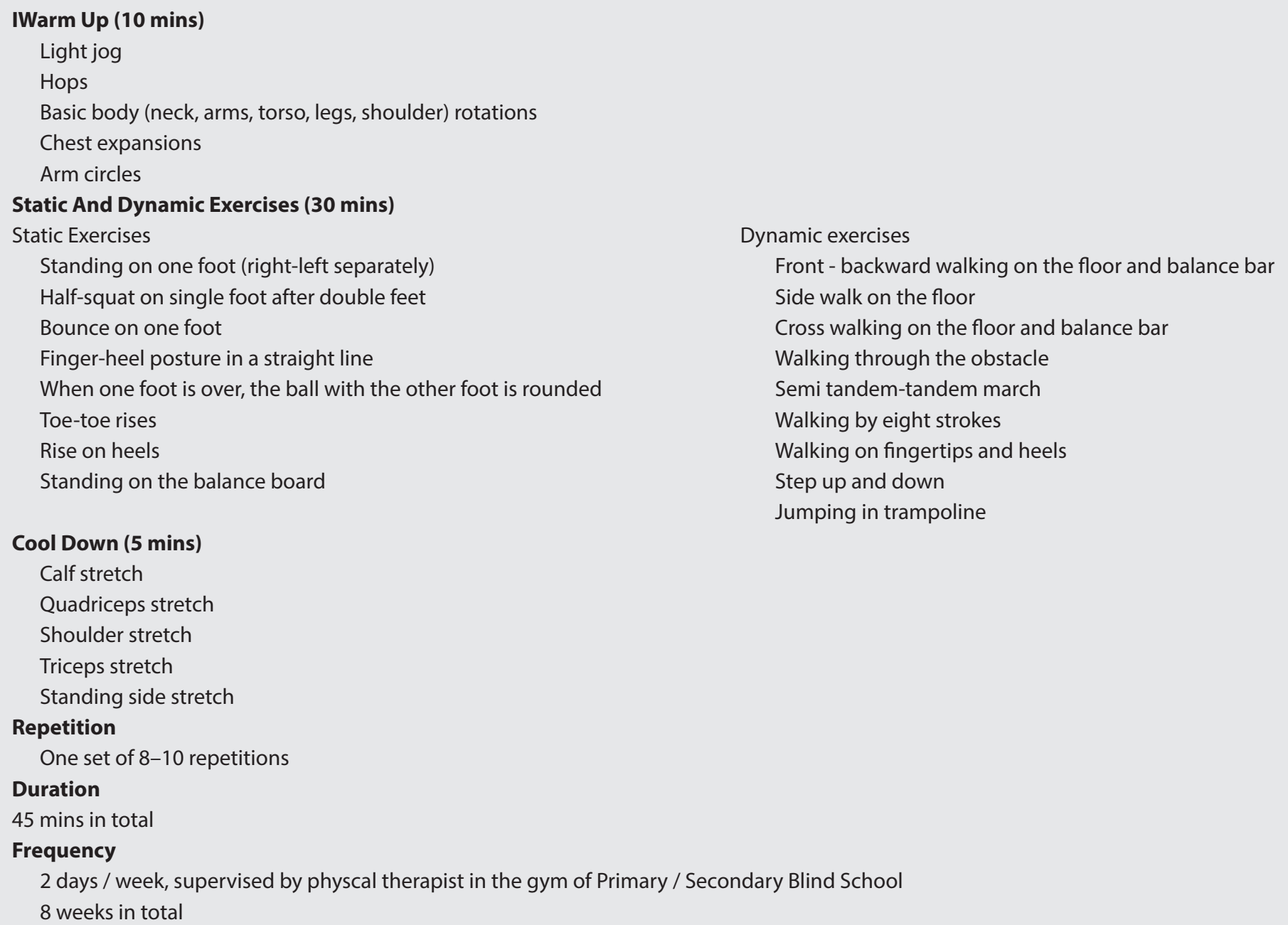

of the leg he/she is standing on. The palms of the hands are placed firmly on the thighs and the task is to hold this balance position for as long as possible. The time measurement is stopped if the child moves the bent leg by separating it from the standing leg or if the hands are moved from the thighs. The time is measured in tenths of a second, until the position was disrupted or the test was over. The test was performed three times with short breaks in between. ${ }^{[24]}$

\section{Balance Training:}

A training program of static and dynamic balance exercises was applied in 2 sessions per week for 8 weeks to all 18 congenitally blind children in the study. The training was carried out in the gymnasium of the Primary / Secondary Blind School. Each training session lasted 45 minutes, starting with a 10-minute warm-up program, followed by a basic exercise training program consisting of 30 minutes static and dynamic exercises, and ending with 5-min cooling down program of stretching exercises. The exercises included in the training program are listed below.

Static Exercises:
1-Standing on one foot (right-left separately) 2-Half-squat on single foot after double feet, 3-Bounce on one foot, 4-Toe-heel posture in a straight line, 5-When one foot is over, the ball with the other foot is rounded, 6-Toe-toe rises, 7-Heel rises, 8-Standing on the balance board

\section{Dynamic exercises:}

1-Front - backward walking on the floor and balance bar, 2-Side walk on the floor, 3-Cross walking on the floor and balance bar, 4-Walking through an obstacle, 5-Semi tandem-tandem march, 6-Walking by eight strokes, 7-Walking on fingertips and heels, 8-Step up and down, 9-Jumping on trampoline All the exercises are shown in Table 1.

\section{Statistical analysis}

The data were analyzed using SPSS vn.16.0 statistics software. Descriptive data were stated as average, standard deviation and percentage. The Wilcoxon signed-rank test was used to determine the differences in before and after-treatment scores. A value of $p \leq 0.05$ was accepted as statistically significant. 


\section{Results}

\section{Participant demographics}

The study included 9 female and 9 male children with a mean age of $10.94 \pm 1.89$ years (range, $7-13$ years). The demographic data of height, weight, and body mass index are shown in Table 2.

\section{Main analysis}

The pre and post-training results of all the balance tests of the 18 congenitally blind children are shown in Table 3 . A statistically significant improvement was determined in all the outcome variables after the training $(p<0.05)$.

\section{Discussion}

Balance is an essential component to be able to perform the activities associated with walking in the context of walkingrelated activities for visually impaired individuals. ${ }^{[25]}$ While dynamic balance needs to be developed for activities such as running and walking, static balance should be developed for activities such as standing and sitting. ${ }^{[26]}$ Although there are many studies showing that balance functions are affected in blind children, there are insufficient exercise approaches to improving the balance functions of these children. ${ }^{[7,9-17]}$ The aim of this study was to improve the balance functions of congenitally blind children. Therefore, a program of 2 sessions per week static and dynamic balance training was applied to the children for 8 weeks. After the training program the balance functions of the congenitally blind children were determined to have increased.

The importance of the degree of loss of visual acuity and / or visual perception is emphasized in the maintenance of balance in visually impaired children. It has been reported that blind children have a lower level of both dynamic and static balance skills than children who have low vision and are healthy. ${ }^{[27,28]}$ Ribadi et al. ${ }^{[9]}$ reported that visual impairment had a lower functional level when compared to both the dynamic and static balance of healthy, blind and low vision adolescents in the 14-17 years age range. Leonard ${ }^{[29]}$ compared the dynamic and static balances of 215 children with visual

\section{Table 2. Demographic characteristics of study children}

\section{Variable}

Age (years)

Height (cm)

Weight $(\mathrm{kg})$

BMI $\left(\mathrm{kg} / \mathrm{cm}^{2}\right)$

SD: Standart deviation; BMI: Body mass index.
Mean \pm SD

$141.62 \pm 11.94$

$36.27 \pm 10.93$

$17.87 \pm 3.22$
$10.94 \pm 1.89$

impairment and a healthy control group, aged $12-20$ years and found that the static balance functions of visually impaired children were worse than those of the healthy children and while static balance was not affected by residual visual perception, dynamic balance was affected. This demonstrated that there may be poor static balance, even if there is residual vision and it indicated that the exercise program to be used in this study needed to include exercises that increase static balance.

Previous studies have emphasized the importance of sight in terms of the development of both static and dynamic balance functions. Although there are studies showing that both static and dynamic balance are affected by the degree of vision loss, to the best of our knowledge, there is only one study in literature related to the development of balance functions. ${ }^{[25]}$ In that study, a mixed group of low vision and blind children performed exercises to improve dynamic balance and dynamic balance functions were evaluated. In the current study however, the training program consisted of both static and dynamic balance exercises to improve both static and dynamic balance functions for blind children, who are the group most affected in terms of balance functions. Rutkowska et al. ${ }^{[30]}$ reported that the balance function was affected in visually impaired children. It was emphasized that the child's age and residual vision are important in this effect and it was stated that physical fitness should be increased in low vision and blind children. Perrin et al. ${ }^{[31]}$ also reported that long-term sporting activity, learning and training could improve dynamic and static postural control in daily life activities.

The harmonious and smooth movement of body parts is con-

Table 3. Pre and post intervention results for all outcome variables

\begin{tabular}{|c|c|c|c|}
\hline Balance Tests & $\begin{array}{c}\text { Pre-training } \\
\text { Mean } \pm S D\end{array}$ & $\begin{array}{l}\text { Post-training } \\
\text { Mean } \pm S D\end{array}$ & p* \\
\hline Walking Forward on a Line (0-4) & $1.94 \pm 1.43$ & $3.44 \pm 0.98$ & 0.001 \\
\hline Standing on One Leg on a Balance Beam F (0-4) & $1.61 \pm 0.91$ & $2.16 \pm 0.85$ & 0.004 \\
\hline Balance Subtest Total Score & $2.75 \pm 1.62$ & $4.52 \pm 1.14$ & 0.001 \\
\hline Timed Up and Go Test (sn) & $10.79 \pm 2.55$ & $7.90 \pm 1.88$ & 0.000 \\
\hline Functional Reach Test (cm) & $36.61 \pm 7.07$ & $45.06 \pm 8.20$ & 0.000 \\
\hline One Legged Stance Test (Right) (sn) & $5.50 \pm 6.09$ & $13.87 \pm 16.86$ & 0.000 \\
\hline One Legged Stance Test (Left) (sn) & $3.58 \pm 2.80$ & $8.97 \pm 8.35$ & 0.000 \\
\hline
\end{tabular}


trolled by the somoto-sensorial and sensory motor systems. Proprioceptive sense is the rhythmic organization of these systems and they work in co-operation with the vestibular system. When there is no vision, proprioception allows you to perceive the position of the joints and to maintain balance while standing. ${ }^{[32]}$ Visually impaired individuals use the somoto-sensorial and vestibular system to compensate for visual impairments in order to maintain balance. This system provides balance and postural stability in their daily lives. ${ }^{[33]}$ Recent research has emphasized that certain physical activities develop proprioception in the joints and long-term training can develop proprioception in the knee and ankle. ${ }^{[33]}$ Jazi et al. ${ }^{[21]}$ stated that the dynamic balance of visually impaired children was developed by improving the proprioceptive and kinesthetic senses, especially those responsible for ensuring balance in the somotosensorial system. It was also reported that the development of the vestibular system could also improve direction finding and orientation skills and that the balance training was also positively affected by the vestibular system performance. ${ }^{[21]}$

In the current study, specialized exercises were used, such as maintaining balance on an unstable floor, different walking methods and standing on one or both legs to stimulate the proprioceptive system while using customized exercises such as single-foot and double-foot splashing, bouncing and walking on different surfaces to stimulate the vestibular system.

As a result, the balance function improved significantly in this group of congenitally blind children after an 8-week exercise program of selected exercises to improve balance.

Balance is one of the important components of the motor skills. Atasavun and Düge ${ }^{[34]}$ compared the motor skills of low vision, blind and healthy children of primary school age. There were balance functions in the motor skills evaluated, and the motor skills of the low vision children were reported to be better than those of the blind and while the motor skills of the healthy children developed, the visually impaired children were left behind. ${ }^{[34]}$ An increase in balance ensures that the individual can perform daily life activities properly and in a controlled manner. Increased independence in daily life activities contributes positively to the development of self-confidence in these children. Therefore, rehabilitation programs for blind children can be considered to be currently lacking and physical exercise programs should be added and widely applied in order to improve balance.

\section{Limitations of study}

The most important limitation of the study was the lack of a control group. The number of children and adolescents meeting our inclusion criteria was low. A control group that did not receive training could not be included because we provide training to all the students who are blind and meet the criteria.

\section{Conclusions}

In congenitally blind children, both static and dynamic balance functions should be developed. The exercise program that was provided in this study to develop static and dynamic balance was determined to have made a significant positive improvement to the balance functions of congenitally blind children.

Conflict of interest: The authors have no conflict of interests to declare.

\section{References}

1. Sindel D. Denge ve Koordinasyon Egzersizleri. In: Diniz F, Ketenci A (ed.) Fiziksel Tıp ve Rehabilitasyon. Nobel Tıp Kitabevi; 2000:22737.

2. Rogers $\mathrm{ME}$, Rogers $\mathrm{NL}$, Takeshima $\mathrm{N}$ et al. Methods to evaluate and improve the physical parameters associated with fall risk in older adults. Preventive Medicine 2003; 36:255-64.

3. Burke RE. Sir Charles Sherrington's the integrative action of the nervous system: a centenary appreciation. Brain 2007; 130:88794.

4. Woollacott M, Shumway-Cook A. Changes in posture control across the life span-A systems approach. Physical Therapy 1990; 70:799-807.

5. Adelson E, Fraiberg S. Gross motor development in infants blind from birth. Child Dev 1974; 45:114-26.

6. Celeste M. A survey of motor development for infants and young children with visual impairments. J Vis Impair Blind 2002; 96:16974.

7. Bouchard D, Tetreault S. The motor development of sighted children and children with moderate low vision aged 8-13. J Vis Impair Blind 2000; 94:564-73.

8. Portfors-Yeomans CV, Riach CL. Frequency characteristics of postural control of children with and without visual impairment. Dev Med Child Neurol 1995; 37:456-63.

9. Ribadi H, Rider RA, Toole T. A comparison of static and dynamic balance in congenitally blind, sighted, and sighted blindfolded adolescents. Adapt Phys Activ Q 1987; 4:220-5.

10. Aydog E, Aydog ST, Cakci A et al. Dynamic postural stability in blind athletes using the biodex stability system. Int J Sports Med 2006; 27:415-8.

11. Häkkinen A, Holopainen $E$, Kautiainen $\mathrm{H}$ et al. Neuromuscular function and balance of prepubertal and pubertal blind and sighted boys. Acta Paediatr 2006; 95:1277-83.

12. Juodzbaliene $V$, Muckus K. The influence of degree of visual impairment on psychomotor reaction and equilibrium maintenance of adolescents. Medicina (Kaunas) 2006; 42:49-56.

13. Schmid M, Nardone A, De Nunzio AM et al. Equilibrium during static and dynamic tasks in blind subjects: no evidence of crossmodal plasticity. Brain 2007; 130:2097-107.

14. Engel-Yeger B. Evaluation of gross motor abilities and self perception in children with amblyopia. Disabil Rehabil 2008; 30:243-8.

15. Houwen S, Visscher C, Lemmink KA et al. Motor skill performance of school-age children with visual impairments. Dev Med Child Neurol 2008; 50:139-45.

16. Ray CT, Horvat M, Croce R et al. The impact of vision loss on postural stability and balance strategies in individuals with profound vision loss. Gait Posture 2008; 28:58-61.

17. Giagazoglou P, Amiridis IG, Zafeiridis A et al. Static balance control and lower limb strength in blind and sighted women. Eur J Appl Physiol 2009; 107:571-9. 
18. Duncan PW, Weiner DK, Chandler J et al. Functional Reach: A New Clinical Measure of Balance. J Gerontol. 1990; 45:192-7.

19. Winter DA. Human balance and posture control during standing and walking. Gait Posture 1995; 3:193-214.

20. Day BL, Streiger MJ, Thompson PD et al. Effect of vision and stance width on human body motion when standing: implications for afferent control of lateral sway. J Physiol 1993;469: 479-99.

21. Jazi SD, Purrajabi F, Movahed A et al. Effect of Selected Balance Exercises on the Dynamic Balance of Children with Visual Impairments. J Vis Impair Blind 2012; 106,466-74.

22. Bruininks RH, Bruininks BD. BOT-2, Bruininks-Oseretsky Test of Motor Proficiency Second Edition, Minneapolis; Minnesota: Pearson Assessments; 2005.

23. Podsiadlo D, Richardson S. The timed "Up \& Go": a test of basic functional mobility for frail elderly persons. J Am Geriatr Soc 1991;39: 142-8.

24. Vellas BJ, Wayne SJ, Romero L et al. One-leg balance is an important predictor of injurious falls in older persons. J Am Geriatr Soc 1997; 45:735-8.

25. Slavoljub U, Goran Z, Radmila K et al. Comparison of the static balance of children with and without visual impairment. Research in Physical Education, Sport and Health 2015; 4,95-9.

26. Gallahue DL, Ozmun JC. Understanding motor development: Infants, children, adolescents, adults ( $6^{\text {th }}$ ed.), Boston; McGraw-Hill;
2006.

27. Brambring M. Divergent development of manual skills in children who are blind or sighted. J Vis Impair Blind 2007; 101:212-25.

28. Horvat M, Ray C, Ramsey VK et al. Compensatory analysis and strategies for balance in individuals with visual impairments. J Vis Impair Blind 2003; 97:695-703.

29. Leonard JA. Static and mobile balancing performance of blind adolescent grammar school children. The New Outlook for the Blind 1969; 63:65-72.

30. Rutkowska I, Bednarczuk G, Molik B et al. Balance Functional Assessment in People with Visual Impairment. J Hum Kinet 2015; 22;99-109.

31. Perrin P, Deviterne D, Hugel F et al. Judo, beter than dance, develops Sensorimotor Adaptibilities Involved in Balance Control. Gait and Posture 2002; 15:187-94.

32. Purves $D$, Augustıne GJ, Fitzpatric $D$, et al. The somotic sensory system. In: Fitzpatric D. Neuroscience ( $3^{\text {rd }}$ ed). Sunderland; MA: Sinauer Associates, Inc; 2012: 202-203.

33. Pereira LM. Spatial concepts and balance performance: motor learning in blind and visually impaired children. J Vis Impair Blind 1990; 84:109-17.

34. Atasavun Uysal, Düger T. A comparison of motor skills in Turkish children with different visual acuity. Fizyoterapi Rehabilitasyon 2011; 22:23-9. 